University of Nebraska - Lincoln

DigitalCommons@University of Nebraska - Lincoln

Effects of mountain beaver management and thinning on 15-yearold Douglas fir growth and survival

\author{
Dan L. Campbell \\ USDA \\ Richard M. Engeman \\ USDA-APHIS-Wildlife Services, s_r100@yahoo.com \\ James P. Farley \\ USDA
}

Follow this and additional works at: https://digitalcommons.unl.edu/icwdm_usdanwrc

Part of the Life Sciences Commons

Campbell, Dan L.; Engeman, Richard M.; and Farley, James P., "Effects of mountain beaver management and thinning on 15-year-old Douglas fir growth and survival" (2015). USDA National Wildlife Research Center - Staff Publications. 1677.

https://digitalcommons.unl.edu/icwdm_usdanwrc/1677

This Article is brought to you for free and open access by the U.S. Department of Agriculture: Animal and Plant Health Inspection Service at DigitalCommons@University of Nebraska - Lincoln. It has been accepted for inclusion in USDA National Wildlife Research Center - Staff Publications by an authorized administrator of DigitalCommons@University of Nebraska - Lincoln. 


\title{
Effects of mountain beaver management and thinning on 15-year-old Douglas fir growth and survival
}

\author{
Dan L. Campbell • Richard M. Engeman • James P. Farley
}

Received: 31 July 2014 / Accepted: 2 March 2015 / Published online: 14 March 2015

(C) Springer-Verlag Berlin Heidelberg (outside the USA) 2015

\begin{abstract}
We examined 4-year growth of 15-year-old damaged and undamaged Douglas fir (Pseudotsuga menzesii) after integrating temporary population reductions of mountain beaver (Aplodontia rufa) with thinning in a pre-commercial hand-planted plantation in western Washington. Five treatment combinations were considered: (1) trapping mountain beavers in an unthinned area, (2) trapping before thinning to 65 trees/ha (160 trees/ac), (3) no trapping and thinning to 65 trees/ha, (4) no trapping and thinning to 146 trees/ha (360 trees/ac), and (5) no trapping and no thinning. Removal of $\geq 90 \%$ of mountain beavers temporarily reduced mountain beaver activity whether the stand was unthinned or thinned. Diameter growth at breast height (dbh) was greater for undamaged trees than for damaged trees in thinned areas. Tree height growth was greatest in trapped areas whether thinned or not. No differences were detected in 4-year survival between trees damaged aboveground and those without aboveground damage, which may be related to undetected root damage to trees without aboveground damage. Basal diameter growth and dbh growth were greatest for areas thinned to 65 trees $/ \mathrm{ha}$. Seventy-
\end{abstract}

Responsible editor: Philippe Garrigues

D. L. Campbell • R. M. Engeman $(\bowtie) \cdot J$. P. Farley

USDA/APHIS/WS National Wildlife Research Center, 4101 LaPorte

Ave., Fort Collins, CO 80521-2154, USA

e-mail: richard.m.engeman@aphis.usda.gov

Present Address:

D. L. Campbell

Wildlife Services Company Inc., 5227 Gifford Rd.,

Olympia, WA 98512, USA

Present Address:

J. P. Farley

USDA/NRCS, 1835 Black Lake Blvd, SW, STE B,

Olympia, WA 98512, USA eight percent of stomachs from mountain beaver trapped in winter contained Douglas fir root or stem materials. Overall, short-term removal of mountain beavers integrated with precommercial thinning promoted growth of crop trees.

Keywords Aplodontia rufa $\cdot$ Damage assessment $\cdot$ Forest animal damage $\cdot$ Population monitoring $\cdot$ Pseudotsuga menziesii $\cdot$ Silvicultural practices

\section{Introduction}

Mountain beavers (Aplodontia rufa) are native burrowing mammals which damage commercial coniferous tree species in much of the forested region west of the crest of the Cascade Range in the Pacific Northwest of the USA (Evans 1984; Campbell 1994). There, they are the greatest source of Douglas fir (Pseudotsuga menziesii) seedling damage (King 1958; Hooven 1977; Borrecco et al. 1979; Black and Lawrence 1992, Cafferata 1992), with damage impacts felt economically (Hooven 1977; Borrecco and Anderson 1980; Campbell and Evans 1988). Mountain beaver damage can suppress height growth, plantation stocking rates, and forest regeneration (Borrecco and Anderson 1980). They occupy a variety of habitats suitable for Douglas fir, red alder (Alnus rubra), western red cedar (Thuja plicata), and other species. Many stands of planted Douglas fir develop large patches of both non-timber-producing plants and other commercial trees (red alder) after mountain beavers have damaged Douglas fir trees or cut planted seedlings. Mountain beavers typically persist in conifer stands unless understory vegetation is shaded out (Cafferata 1992). After timber harvest, mountain beavers usually expand populations and cause extensive damage to subsequent tree crops (Cafferata 1992). Mountain beavers 
have been well documented to destroy newly planted tree seedlings, and also girdle stems and roots or undermine root systems of pre-commercial trees about 8 to 20 years old (e.g., Cafferata 1992). Wet snow or ice storms make young trees planted on slopes particularly vulnerable to loss from root girdling. Before the present study, little clarity existed whether Douglas fir stems and roots were used as food or as bedding material by mountain beavers, especially since examinations of mountain beaver nests (Carey et al. 1989), and winter food caches (Farley and Campbell 1992) did not reveal what use mountain beavers made of the materials obtained by girdling Douglas fir stems and roots.

A variety of studies have been conducted to determine methods for reducing mountain beaver damage (Arjo and Nolte 2006; Arjo et al. 2007; Campbell and Evans 1988, 1989; Campbell et al. 1992). Exclusion using small-diameter plastic mesh "Vexar" seedling protectors is an effective method to prevent much of the damage to young seedlings by mountain beavers and several other species (Campbell and Evans 1975), but large wire cages have been ineffective because mountain beavers either climb into them or dig under them. BGR-P repellent was registered for mountain beavers, and this or other repellents may cause long-term avoidance (Campbell et al. 1987; Campbell 1994). However, these methods have not been tested on older, larger trees.

Since mountain beaver damage occurs in both thinned and unthinned stands, managers cannot be sure of optimal silvicultural prescriptions to apply for promoting tree growth. Hoyer et al. (1979) found mountain beaver girdling damage unrelated to tree spacing, with damage continuing near mountain beaver activity, and then declining with distance from activity. Mountain beavers do not thin commercial conifer stands in uniform patterns and can significantly devalue areas because of their damage. Although population suppression through trapping has been conducted in precommercial stands, it can be difficult and expensive, and it has been uncertain if integrating trapping with pre-commercial thinning benefits tree growth.

As part of a more recent strategy, mountain beavers may be removed after logging and prior to planting tree seedlings to reduce damage to new seedlings, but invasion by non-resident mountain beavers and residual populations of resident animals quickly fills existing burrow systems and suitable habitats (e.g., Arjo and Nolte 2006). Mountain beaver foraging (Martin 1971) often keeps areas around burrow systems void of conifers, resulting in large commercially unproductive areas, with the "voids" often filled with brushy species, or with red alder.

One problem in assessing mountain beaver damage impacts on trees is how to measure effects of root cutting and root girdling. Part of the present study examined food habits of mountain beavers trapped in two of our treatment areas to assess whether mountain beavers consumed the outer tissue of Douglas fir roots, or simply cut roots out of their way when burrowing. This "unseen" damage may cause tree mortality whether visibly girdled aboveground or not. Some trees may fall over while small, while others may be near commercial size before falling from root damage. Other root damaged trees may be affected by reduced growth, and some trees not recognized as damaged may be affected by root damage. Moreover, aboveground damage by black bear (Ursus americanus) and porcupine (Erethizon dorsatum) can appear similar to aboveground mountain beaver damage. Documenting aboveground tree portions in mountain beaver diet provides absolute confirmation of mountain beaver damage, beyond the close association between damage and nearby mountain beaver burrows.

This study was conducted on a mountain beaver damaged but potentially productive Douglas fir site to help forest managers assess and integrate mountain beaver population reductions and pre-commercial thinning. Study results may also apply to commercial thinning as a replacement for precommercial thinning as small-diameter logs become preferred for milling. Comparisons of growth and survival cover a 4year period on adjacent treatment areas by removing mountain beavers and/or by thinning trees to two standard thinning densities.

\section{Study area and methods}

\section{Study area}

The study area was in the Lower Chehalis State Forest, southeastern Grays Harbor County, Washington, and consisted of a relatively uniform 139-ha 15-year-old (at study initiation), unthinned, mountain beaver damaged stand of Douglas fir, averaging about $11 \mathrm{~m}$ tall and about $14 \mathrm{~cm}$ at diameter breast high (dbh). Average elevation was about $61 \mathrm{~m}$. Moderate slopes of about 10 to $18 \%$ had northeasterly exposure. Before the start of the study, Department of Natural Resources foresters found $62 \%$ of the trees damaged by mountain beaver, and $42 \%$ of those had at least $75 \%$ of the surface of the stem girdled near the ground (M. Mauren, personal communication).

The original plantation was planted 15 years prior with Douglas fir at higher than normal density 334 trees/ha $(825$ trees/ac) to help compensate for expected losses of trees to mountain beaver damage (typical planting density was 130 seedlings/ha and 65 trees/ha after 3 years). In 1990, all portions of the study area were occupied by mountain beavers, usually living in and along brushy openings caused by mountain beaver killed trees. Otherwise, the Douglas fir canopy had shaded out much of the ground vegetation needed by mountain beavers. Old girdling and unoccupied mountain beaver burrows were common under closed canopies. Trees near 
active mountain beaver burrows continued to have their bases girdled or partially girdled. Many trees with root damage had fallen before the study, and others, both with and without obvious (aboveground) damage, fell during the study.

This was a long-term study conducted in difficult habitats on difficult terrain using five large, similar stands of Douglas fir trees. Human, fiscal, physical, and logistical resources made treatment replication impossible. Thus, inferences from our results are aimed at this large study area, as reflected in the analytical methods. Due to the Douglas fir monoculture and the great similarity among the areas used for the applied treatments, observed differences in growth and survival among the areas are best explained by the treatments applied to the areas rather than assuming inherent differences among the areas.

\section{Experimental treatments and observations}

The study area was divided into five areas for treatment purposes, each with a similar distribution of mountain beaver damage and apparent activity. Within each treatment area, 100 visibly mountain beaver damaged trees and 100 trees visibly undamaged, all of similar size, were selected for study. To insure that both undamaged and damaged trees were uniformly represented throughout each treatment area, damaged and undamaged trees were paired spatially with inter-pair spacings $\geq 18 \mathrm{~m}$. Treatments consisted of the following: (1) trapped only; mountain beavers were trapped in December 1990 and January-February 1991, but the trees were not thinned; (2) mountain beavers were trapped during the same time period, and trees were thinned to 65 trees/ha; (3) trees were thinned to 65 trees/ha with no trapping; (4) trees were thinned to 146 trees/ha with no trapping; and (5) a control area with no trapping or thinning.

Prior to thinning in March 1991, sample trees were marked with a numbered metal tag attached to a branch, flagged, the upper trunk marked with tree paint, and mapped for relocation after thinning. Each sample tree was measured to determine the diameter at the base $1 \mathrm{~m}$ above ground level, the amount circumference girdled (for damaged trees), and the dbh. Tree heights were taken on 10 randomly selected pairs of damaged trees and undamaged trees in each treatment area.

Damaged trees were selected based on obvious aboveground damage and the presence of an active mountain beaver burrow within $1 \mathrm{~m}$ of the base of the tree. Undamaged trees appeared healthy and did not have visible mountain beaver burrows near the tree but may have had undetected root damage.

Within each treatment area, 10 active mountain beaver burrow systems, located at least $91 \mathrm{~m}$ apart, were numbered, flagged, marked with polyvinyl chloride pipe, and mapped for relocation. Mountain beaver activity indicators, consisting of marked sword fern bundles, were installed in five burrows in each burrow system to determine activity (Engeman et al.
1991). Before trapping by commercial trappers, the mountain beaver systems in two treatment areas were marked with concealed radio transmitters for efficient relocation, and the burrow markers temporarily removed. Trapping was done only before thinning because of the physical difficulty of trapping in thinned slash.

Trappers were contracted to remove $\geq 90 \%$ of the mountain beavers from each of the two assigned treatment areas. To determine trapping efficacy, mountain beaver activity indicators were reinstalled within $48 \mathrm{~h}$ after trapping was completed, with trapping repeated until the required percentage of animals was removed from each area. Activity was subsequently measured annually on all treatment areas.

Trapped mountain beavers were examined to determine which plant species, and quantities of plants, were found in stomach contents. Characteristics of plants were determined from reference plant samples collected from the study area. The plant samples taken from stomachs of 25 adult males and 25 adult females were identified and quantified at the Washington State University Food Habits Laboratory.

Observations were made annually. For surviving trees, tree height growth, dbh growth, and basal diameter growth were analyzed as in a two-factor ANOVA with initial tree condition (damaged or undamaged) and treatment as the main effects. We note that growth of stem bases and dbh are not necessarily the same, because nutrients sometimes enlarge diameters directly above partial injury (damage) to the tree stem. Because we wanted to make individual comparisons among each of the five treatment groups for the three measurement variables (rather than having a smaller set of a priori comparisons of particular interest), we applied Duncan's multiple range test with an experiment-wise error rate of 0.05 to identify differences among treatment means. To analyze the proportions of damaged and undamaged trees surviving for 4 years, within each treatment, we applied Fisher's "exact" test, because contingency table cells were either at or near zero, or at or near $100 \%$.

\section{Results}

Mountain beaver activity and stomach contents

Trappers removed 39 mountain beavers from the unthinned trapped area, including all animals from the 10 sample plots marked only with hidden radio transmitters. Trappers also removed 183 mountain beavers from the area subsequently thinned to 65 trees/ha. This area had to be trapped two times to remove $90 \%$ of the mountain beavers from the 10 sample burrow systems marked by radio transmitters. Mountain beaver activity in the unthinned trapped area dropped to $0 \%$, while activity in the trapped area thinned to 65 trees/ha dropped to $10 \%$ (Table 1). In the subsequent 3 years, activity 
Table 1 Percent mountain beaver activity in five treatment areas, based on removal of sword fern activity indicators in permanent sample plots $(N=10 /$ area)

\begin{tabular}{|c|c|c|c|c|c|c|}
\hline \multicolumn{2}{|l|}{ Treatment } & \multirow[t]{2}{*}{ Pre-trapping } & \multirow[t]{2}{*}{ Post-trapping } & \multirow{2}{*}{$\begin{array}{l}1 \text { year post- } \\
\text { trapping }\end{array}$} & \multirow{2}{*}{$\begin{array}{l}2 \text { years post- } \\
\text { trapping }\end{array}$} & \multirow{2}{*}{$\begin{array}{l}3 \text { years post- } \\
\text { trapping }\end{array}$} \\
\hline Trapping & Thinning & & & & & \\
\hline \multirow[t]{2}{*}{ Yes } & No & 100 & 0 & 40 & 50 & 60 \\
\hline & 65 trees/ha & 100 & 10 & 60 & 40 & 90 \\
\hline \multirow[t]{3}{*}{ No } & No & 100 & 100 & 80 & 80 & 80 \\
\hline & 65 trees/ha & 100 & 100 & 70 & 60 & 60 \\
\hline & 146 trees/ha & 100 & 100 & 40 & 90 & 60 \\
\hline
\end{tabular}

increased and ranged from 40 to $60 \%$ in the unthinned trapped area and 40 to $90 \%$ in the trapped area thinned to 65 trees/ha, indicating a temporary but substantial population suppression, followed by mountain beaver population recovery to levels observed within the other treatment areas (40$90 \%$, Table 1). Examination of the stomachs of 50 selected adult mountain beavers showed that $78 \%$ of stomachs contained Douglas fir root and stem materials, and $52 \%$ contained Douglas fir needles.

dbh and basal growth

Differences in actual dbh growth were most pronounced among treatment areas $\left(\mathrm{F}_{4,932}=40.59, p=0.0001\right)$ but were also found between damaged and undamaged trees $\left(\mathrm{F}_{1,932}=\right.$ 5.53, $p=0.0212$ ) and the interaction of tree condition with treatment $\left(\mathrm{F}_{4,932}=3.22, p=0.0122\right)$. Differences in percent $\mathrm{dbh}$ growth were only found among treatments $\left(\mathrm{F}_{4,932}=\right.$ $22.25, p=0.0001)$, but not between tree conditions $\left(\mathrm{F}_{1,932}=\right.$ $2.45, p=0.1179)$, nor the interaction $\left(\mathrm{F}_{4,932}=1.76, p=0.1351\right)$. The trees in the area trapped and thinned to 65 trees/ha had superior actual and percent dbh growth over all other treatments (Table 2). The trapped/unthinned and untrapped/ unthinned areas were statistically indistinguishable and had the least actual and percent dbh growth (18.4 and $16.6 \%$, respectively). Both the untrapped and thinned to 65 trees/ha area and the untrapped and thinned to 146 trees/ha area had superior dbh growth (Table 2) than the two areas with no thinning (i.e., trapped with no thinning and untrapped with no thinning). Furthermore, the $25.7 \%$ dbh growth for the untrapped and thinned to 65 trees/ha area was detectably superior to the $21.6 \%$ dbh growth for the untrapped and thinned to 146 trees/ha area (Table 2).

Again, differences were detected among treatments when considering actual basal growth $\left(\mathrm{F}_{4,932}=51.15, p=0.0001\right)$, and also between initially damaged and undamaged trees $\left(\mathrm{F}_{1,932}=3.80, p=0.0516\right)$, but an interaction was not detected $\left(\mathrm{F}_{4,932}=1.23, p=0.2958\right)$. Like for dbh, differences were only found among treatments when examining percent basal growth $\left(\mathrm{F}_{4,932}=30.83, p=0.0001\right)$. As would be expected from the above results, the area trapped and thinned to 65 trees/ha had the superior actual and percent basal diameter growth among all treatments (33.2\%), with the untrapped area thinned to 65 trees/ha the next best (30.6\%) (Table 2). Again, the two unthinned areas fared worse than the others with $19.6 \%$ basal diameter growth for trapped and $18.5 \%$ for untrapped (Table 2).

\section{Height growth}

Differences among the treatment areas were evident for both actual and percent height growth $\left(\mathrm{F}_{4,86}=3.45, p=0.0115\right.$ for actual growth; $\mathrm{F}_{4,86}=4.79, p=0.0015$ for percent growth), with the differences occurring irrespective of whether the trees were damaged or undamaged to begin with, i.e., interactions were not detected $\left(\mathrm{F}_{4,86}=1.44, p=0.2269\right.$ for actual growth; $\mathrm{F}_{4,86}=2.14, p=0.0823$ for percent growth). The trapped, but unthinned area had the greatest height growth ( $31 \%$ average), followed by the trapped area thinned to 65 trees/ha, while the untrapped area thinned to 146 trees/ha had the least height growth (16.4\% average) (Table 2). The other three treatments showed similar height growth (21.9-24.7\%) (Table 2).
Table 2 Average percent and absolute growth for three growth variables for similar-sized trees (combined mountain beaver damaged and undamaged) under five-treatment mountain beaver trapping/thinning regimes

\begin{tabular}{|c|c|c|c|c|c|c|c|}
\hline \multicolumn{2}{|l|}{ Treatment } & \multicolumn{2}{|c|}{ Diameter (dbh) growth } & \multicolumn{2}{|c|}{ Basal diameter growth } & \multicolumn{2}{|c|}{ Height growth } \\
\hline Trapping & Thinning & $\%(\mathrm{SE})$ & $\mathrm{cm}(\mathrm{SE})$ & $\%(\mathrm{SE})$ & $\mathrm{cm}(\mathrm{SE})$ & $\%(\mathrm{SE})$ & $\mathrm{m}(\mathrm{SE})$ \\
\hline \multirow[t]{2}{*}{ Yes } & No & $18.4(0.7)$ & $2.51(0.10)$ & $19.6(1.0)$ & $3.51(0.18)$ & $31.0(2.4)$ & $3.21(0.19)$ \\
\hline & 65 trees/ha & $29.0(0.6)$ & $4.11(0.09)$ & $33.2(0.8)$ & $6.10(0.15)$ & $24.7(2.9)$ & $2.83(0.32)$ \\
\hline \multirow[t]{3}{*}{ No } & No & $16.6(1.2)$ & $2.01(0.15)$ & $18.5(1.6)$ & $2.90(0.21)$ & $21.9(1.9)$ & $2.30(0.21)$ \\
\hline & 65 trees $/$ ha & $25.7(1.2)$ & $3.51(0.19)$ & $30.6(1.2)$ & $5.26(0.18)$ & $22.2(2.5)$ & $2.36(0.22)$ \\
\hline & 146 trees/ha & $21.6(1.0)$ & $3.10(0.13)$ & $22.3(1.0)$ & $4.17(0.17)$ & $16.4(2.8)$ & $2.02(0.33)$ \\
\hline
\end{tabular}


Tree survival

Four-year survival was very high for both damaged and undamaged trees. It ranged from 91 to $97 \%$ across treatments for damaged trees with no differences detected among 4-year survival rates (Fisher's exact test, $p=0.242$ ). Survival of undamaged trees ranged from 96 to $100 \%$ across treatments. Even though survival was uniformly very high, the differences in survival approached statistical detectability (Fisher's exact test, $p=.071$ ) due to two treatments having $100 \%$ survival (trapped and unthinned; untrapped and unthinned).

\section{Discussion}

Integrating short-term suppression of mountain beaver populations with pre-commercial thinning on this highly productive Douglas fir site indicated improved tree growth over 4 years. Thinning to 65 trees/ha, accompanied by trapping and removal of at least $90 \%$ of the mountain beavers just prior to thinning, resulted in the greatest growth at dbh. Even though the sites were reinvaded, there appeared to be less subsequent damage. Although tree growth dbh improved by thinning, growth on areas thinned to either 146 or 65 trees/ha were very similar to when there was no trapping of mountain beaver. The two areas where mountain beaver populations were suppressed had greatest height growth, reflecting previous research that reported that mountain beaver damage can suppress height growth (Borrecco and Anderson 1980).

That mountain beavers also consume the portions of roots and stems of damaged trees besides using the materials for bedding confirms this role in their damage. The primarily problem resulting from root damage in the study area was of weakened trees falling. Beyond wind or snow toppling weakened trees, increasing weight from branches on one side of the tree also caused trees to fall. All of our treatment areas also had some tree mortality from root rot but could not be directly associated with mountain beaver activity, especially as this was not a focus of our study.

A longer-term evaluation started at an earlier tree age for pre-commercial or commercial thinning would be valuable, as smaller-diameter trees are often favored for ease in processing and using smaller equipment. Another consideration might be to evaluate whether reducing post-control mountain beaver reinvasion is effective in reducing later damage. Reinvasion by mountain beaver to a clear-cut can be substantially reduced by locating and destroying mountain beaver nests after animals are removed (Campbell 1993). Ideally, this removal would be done prior to timber harvest and replanting, and population densities may remain low into pre-commercial thinning. Similarly, prior to thinning, destruction of mountain beaver nests after trapping would likely provide the stand long-term protection from further damage by deterring reinvasion.

Further evaluation of alternate forage as a deterrent to tree damage is also needed for mountain beavers (Arjo and Nolte 2006; Arjo et al. 2007). Having preferred forage available can potentially reduce damage to conifers from late winter to early summer, especially with an abundance of evergreen forbs preferred by black bear, black-tailed deer (Odocoileus hemionus columbianus), mountain beaver, snowshoe hare (Lepus americanus), Roosevelt elk (Cervus canadensis roosevelti), and grouse (Campbell, personal observation, Campbell and Evans 1978; Poelker and Hartwell 1973). The availability of plant sugars may be one of the most attractive plant components (Radwan and Campbell 1967). Tree thinning stimulates the regrowth of existing forage species which may be preferred by mountain beavers over Douglas fir, but supplemental seeding of fire-resistant preferred forbs may reduce longterm mountain beaver damage and generally improve the quality and abundance of wildlife forage in thinned stands.

Other management considerations should include the benefit of protecting red alder from mountain beaver. Once considered a "competing weed species," rapid growing red alder has become a valuable crop for export to Europe for furniture, cabinets, paper, etc. In recent years, red alder is often of more value at harvest than Douglas fir. When few conifer stands are harvested, older stands of mixed conifer and hardwoods, including red alder, become more valuable as wildlife habitat. However, when considering red alder for plantations, one must also consider that mountain beaver, elk, frost pockets (due to poor air drainage), and storm damage can severely damage red alder.

Mountain beaver trapping in pre-commercially or commercially thinned sites should be carefully monitored to assure that a high proportion of the animals are removed, i.e., at least $90 \%$. This can be achieved by determining pre-trapping and post-trapping activity (Engeman et al. 1991). For contract evaluation, selected active systems should be marked without trappers having knowledge of the locations. These can be relocated to install activity monitors immediately after trapping, using transmitters, GPS, or other methods. There should be at least one active burrow monitored for each 4 ha on larger units ( $\geq 40$ ha), and about one system monitored for each 1 to 2 ha on smaller units.

\section{Conclusions}

1. Combining short-term suppression of mountain beaver populations just prior to pre-commercial thinning on our highly productive Douglas fir site improved tree growth over 4 years, with thinning to 65 trees/ha resulting in greatest dbh growth. 
2. Mountain beavers were confirmed to consume root and stem materials of trees (in addition to using the materials for bedding).

3. Removal of mountain beavers should be carefully monitored to assure that a high proportion ( $\geq 90 \%)$ of the animals are removed, which can be accomplished using activity indicators in active systems pre- and post-control.

4. A longer-term evaluation initiated at an earlier tree age of mountain beaver population suppression in combination with pre-commercial or commercial thinning would be valuable for circumstances where smaller-diameter trees are desired for harvest.

\section{References}

Arjo WM, Nolte DL (2006) Boomer or bust: managing a Pacific Northwest pest species. In: Timm RM, O’Brien JM (eds) Proc. 22nd Vertebr. Pest Conf., Univ. of Calif.-Davis, Davis, CA, p 181186

Arjo WM, Huenefeld RE, Nolte DL (2007) Mountain beaver home ranges, habitat use, and population dynamics in Washington. Can J Zool 85:328-337

Black HC, Lawrence WH (1992) Animal damage management in Pacific Northwest forests: 1901-1990. In: Black HC (ed) Silvicultural approaches to animal damage management in pacific northwest forests. USDA, Forest Service, Pacific Northwest Research Station. Tech. Rep. PNW-GTR-287. Portland, OR, p 23-55

Borrecco JE, Anderson RJ (1980) Mountain beaver problems in the forests of California, Oregon, and Washington. In: Clark J, Marsh RE (eds) Proc 9th Vertebr. Pest Conf.Univ. of Calif.-Davis, Davis, CA, p 135-142

Borrecco JE, Anderson RJ, Black HC, Evans J, Guenther KS, Lindsey GD, Mathews RP, Moore TK (1979) Survey of mountain beaver damage to forests in the Pacific Northwest, 1977. State of Washington, Dept. of Natural Resources, DNR Note \#26, Olympia, WA

Cafferata S (1992) Silvicultural methods in relation to selected wildlife species-mountain beaver. In: Black HC (ed) Silvicultural approaches to animal damage management in Pacific Northwest forests. USDA, Forest Service, Pacific Northwest Research Station, Technical Report PNW-GTR-287, Portland, p 231-251

Campbell DL (1993) Nest removal reduces reinvasion by mountain beaver (Aplodontia rufa). Northwest Sci 67:126

Campbell DL (1994) Mountain beavers. In: Hygnstrom S, Timm R, Larson G (eds) Prevention and control of wildlife damage, great plains animal damage. University of Nebraska, Lincoln, pp B-53B-60

Campbell DL, Evans J (1975) "Vexar" seedling protectors to reduce wildlife damage to Douglas-fir. Leaflet No. 508., USDI Fish Wild. Serv., Washington, DC

Campbell DL, Evans J (1978) Establishing native forbs to reduce blacktailed deer damage to Douglas-fir. Proc. 8th Vertebr. Pest. Conf. Univ. Cal. Davis, p 145-151

Campbell DL, Evans J (1988) Recent approaches to controlling mountain beavers (Aplodontiarufa) in Pacific Northwest forests. In: Crabb AC, Marsh RE (eds) Proc. 13th Vertebr. Pest Conf. Univ. of Calif.Davis, Davis, CA, p 183-187

Campbell DL, Evans J (1989) Aversive conditioning with thiram to reduce mountain beaver damage to Douglas fir seedlings. Northwest Sci 63:70

Campbell DL, Evans J, Engeman RM (1987) Deer repelled from Douglas-fir new growth using BGR-P and aversive conditioning. Washington State Department of Natural Resources Technical Publication, No. 46, Olympia, WA

Campbell DL, Farley JP, Engeman RM (1992) Field efficacy of pelleted strychnine baits for control of mountain beavers (Aplodontiarufa). In: Borrecco JE, Marsh RE (eds) Proc. 15th Vertebrate Pest Conf., $p$ 335-339

Carey MC, Campbell DL, Campbell CL (1989) Physical structure, flora, and fauna of mountain beaver nests. Northwest Sci 63:70

Engeman RM, Campbell DL, Evans J (1991) An evaluation of 2 activity indicators for use in mountain beaver burrow systems. Wildl Soc Bull 19:413-416

Evans J (1984) Mountain beaver. The encyclopedia of mammals. In: MacDonald P (ed) Facts on file. Facts on File Publ, New York, p 610-611

Farley JP, Campbell DL (1992) Winter food caching by mountain beavers (Aplodontiarufa) in a girdled Douglas fir stand. Northwest Sci 66: 120

Hooven EF (1977) The mountain beaver in Oregon: its life history and control. Res. Paper 30. Oregon State Univ. Forest Res. Lab, Corvallis OR

Hoyer GE, Anderson N, Riley R (1979) A case study of six years of mountain beaver damage on the Clallam Bay western hemlock plots. Wash. Dept. Nat. Res., DNR Note No. 28, Olympia, WA

King JE (1958) Development of a stand of coniferous reproduction and interplanted Douglas-fir. Northwest Sci 32:1-8

Martin P (1971) Movements and activities of the mountain beaver (Aplodontiarufa). J Mammal 51:717-723

Poelker RJ, Hartwell HD (1973) Black bear of Washington. Biol. Wash. State Game Dept. Bull. No. 14

Radwan MA, Campbell DL (1967) Snowshoe hare preferences for spotted catsear flowers in western Washington. J Wildl Manag 32:104108 